удк 338.436:330.341.1

DOI: https://doi.org/10.32851/2708-0366/2020.3.10

Крикунова В.М.

кандидат економічних наук, доцент, доцент кафедри готельно-ресторанного та туристичного бізнесу й іноземних мов,

Херсонський державний аграрно-економічний університет ORCID: https://orcid.org/0000-0001-5710-8029

Карнаушенко А.C.

кандидат економічних наук,

Херсонський державний аграрно-економічний університет

ORCID: http://orcid.org/0000-0003-1813-2792

Krykunova Viktoriia

Kherson State Agrarian and Economic University

Karnaushenko Alla

Kherson State Agrarian and Economic University

\title{
МЕТОДИКА ОЦІНКИ ЕФЕКТИВНОСТІ ФІНАНСУВАННЯ ІННОВАЦІЙНОЇ ДІЯЛЬНОСТІ МОЛОДІЖНИХ ПІДПРИЄМСТВ
}

\section{EFFECTIVENESS EVALUATION METHOD OF FINANCING INNOVATION YOUTH ENTERPRISES}

У статті розглядаються особливості оцінки ефективності фінансування інноваційної діяльності молодіжного підприємництва. Авторами запропоновано використовувати показники трьох груп із метою більи якісної оцінки економічної ефективності фінансування. У дослідженні визначено найбільш вагомі критерї оцінки ефективності фінансування інноваційної діяльності молодіжних підприємств, які повинні віддзеркалювати економічну доиільність тих чи інших альтернативних джерел. Доведено, шчо на ефективність фінансування інновачійної діяльності молодіжних підприємств впливає оптимальність співвідношення внутрішніх та зовнішніх джерел. Аналізуючи ефективність залучення додаткових грошових коштів, виявлено, шуо на нього впливають кількісні та якісні фактори. Встановлено, щзо головним фінансовим інструментом політики стимулювання інноваційного розвитку молодіжних підприємств є використання кочтів державного бюджету, а основним показником, який визначає рівень відповідності науки завданням інноваційного розвитку економіки, є наукоємність ВВП.

Ключові слова: молодіжне підприємство, фінансування, методика оцінки, ефективність, інновачійна діяльність, інвестиції.

В статье рассматриваются особенности оценки эффективности финансирования инновачионной деятельности молодежного предпринимательства. Авторами предложено использовать показатели трех групп с иелью более качественной оценки экономической эффективности финансирования. В исследовании определены наиболее значимые критерии оченки эффективности финансирования инновационной деятельности молодежньх предприятий, которые должны отражать экономическую иелесообразность тех или иньх альтернативных источников. Доказано, что на эффективность финансирования инновационной деятельности молодежных предприятий влияет оптимальное соотношения внутренних и внешних источников. Анализируя эффективность привлечения дополнительных денежных средств, выявлено, что на него влияют количественные и качественные факторы. Установлено, что главныл финансовыл инструментом политики стимулирования инновационного развития молодежных предприятий является использование средств государственного бюджета, а основным показателем, определяющим уровень соответствия науки задачам инновационного развития экономики, является наукоемкость ВВП.

Ключевые слова: молодежное предприятие, финансирование, методика оценки, эффективность, инновационная деятельность, инвестиции. 
The purpose of the article is to determine the features of assessing the effectiveness of financing the innovative activities of youth enterprises. The methodological basis of this article is the methods of scientific knowledge, in particular, the following methods were used in the study: monographic - in studying the evolutionary views of economists to assess the effectiveness of financing the innovative activities of youth enterprises; analysis and synthesis - in the study of scientific papers, laws and regulations and the practice of assessing the effectiveness of financing innovation; systematization - in the study of socioeconomic phenomena and processes studied during the study; scientific abstraction - in determining the purpose, objectives and formulation of the conclusions of this article. The authors propose to use the indicators of the three grouped groups in order to better assess the economic efficiency of financing. The study identifies the most important criteria for assessing the effectiveness of financing the innovative activities of youth enterprises should, which should reflect the economic feasibility of certain alternative sources. It is proved that the efficiency of financing the innovative activity of youth enterprises is influenced by the optimal ratio of internal and external sources. Analyzing the effectiveness of raising additional funds, it was found that it is influenced by quantitative and qualitative factors. It is established that the main financial instrument of the policy of stimulating innovative development of youth enterprises is the use of state budget funds, and the main indicator that determines the level of compliance of science with the tasks of innovative economic development is the knowledge intensity of GDP. Evaluation of financing of innovative activity at internal and external investment should be carried out by a technique of an estimation of economic efficiency of investments which should be statistical or dynamic. The study found that the main and essential difference between the dynamic method and the statistical method is the discounting of cash flows. The authors determined that the most important dynamic indicators of investment in innovation are net present (present) value, internal rate of return on investment, return on investment (or return on investment index) and the discounted payback period. It is established that the assessment of the effectiveness of attracting credit resources is carried out according to three main methods. According to the study of the effectiveness of attracting credit resources, the following rule is established: the excess of profit from the project over the amount of interest paid on the loan used to finance this project is a necessary condition for the feasibility of the project.

Key words: youth enterprise, financing, evaluation methods, efficiency, innovative activity, investments.

Постановка проблеми. Сучасність вимагає від суб'єктів господарювання відкритості ринкових відносин та посиленої конкурентоспроможності за рахунок використання інноваційних технологій та створення принципово нової продукції, які впливають на вдалу фінансово-господарську діяльність підприємств, а в подальшому - на піднесення економіки країни. Інновації та інноваційна діяльність $є$ потрібною частиною процесу забезпечення вдалої, тривалої та стійкої роботи молодіжного підприємства та залишається однією 3 грунтовних складових частин продуктивної стратегії забезпечення конкурентних пріоритетів. Нині необхідність в активізації інноваційної діяльності натикається на безсистемність процесу запровадження інноваційної діяльності, їх комплектного використання, недосконалість, а місцями і відсутність формалізованого пристосування через прийняття управлінських рішень та розуміння їх кінцевих результатів, невизначеність прибуткового механізму керівництва інноваційною діяльністю фірм. У зв'язку з цим виникає потреба у класифікації вже існуючих досліджень та їх подальшому опрацьовуванні, і насамперед у розгляді ефективності інноваційної діяльності як основи прийняття рішень.

Першочерговою проблемою запровадження інновацій молодіжними підприємствами є низька ефективність та недостатність обсягів його фінансування. Відомі українські вчені Ю.Ф. Мельник та П.Т. Саблук визначили, що до рівня технологічної потреби інноваційного процесу молодіжних підприємств необхідно додатково залучити за 10-12 років більше 300 млрд. грн [1], а на сучасному етапі розвитку ця сума $\epsilon$ утопічною для молодих власників підприємств. Для формування структури джерел фінансування інноваційної діяльності необхідно дослідити ефективність їх викори- 
стання на підприємстві, тому актуальним питанням $є$ визначення методики оцінки ефективності фінансування інноваційної діяльності молодіжних підприємств.

Аналіз останніх досліджень та публікацій. Різні аспекти проблем оцінки ефективності фінансування інноваційної діяльності підприємств висвітлювалися у роботах таких науковців, як: А. Чупіс, С. Закоморний, Н. Гринюк, І. Балабанов, В. Федоренко, Ю. Пінчук, Ю. Воробйов, Б. Холод, А. Пересада, А. Давидов, В. Кузьмінський та ін. Незважаючи на велику кількість досліджень, які присвячені цій тематиці, залишається не повною мірою охопленою оцінка ефективності фінансування інноваційної діяльності саме молодіжних підприємств.

Формулювання цілей статті. Ціллю статті $є$ визначення особливостей оцінки ефективності фінансування інноваційної діяльності молодіжних підприємств.

Виклад основного матеріалу. Нині інновації $є$ одними із найскладніших подій у діяльності молодіжних підприємств, що розкриває економічний ріст, розвиток і стабільність фінансово-господарської діяльності будь якої фірми. Розкриваючи поняття інновації, встановлено, що воно асоціюється в молодих власників підприємств як творчий процес у вигляді виготовлення нових споживчих цінностей, вживання яких потребує, щоби споживачі змінили звичайні шаблони. У широкому судженні - це передові технологічні, соціальні та економічні зміни, певні новації у виробничій, фінансовій, науково-дослідницькій та інших галузях, поява сучасних прийомів виробництва, виготовлення та надання нових видів продукції та послуг, освоєння нових ринків реалізації, будь яке удосконалення, яке покриває економію витрат або створює умови для такої економії. У зв'язку з вищевикладеним встановлено, що інноваціями $\epsilon$ підсумковий результат інтелектуальної діяльності (технологічних експериментів, наукових відкриттів і винаходів та реалізація наукових ідей) у вигляді нового об'єкта (системи, технології, обладнання, товарів і послуг) або у вигляді предмета, що якісно відрізняється від останнього аналога.

Ефективність фінансування інноваційної діяльності молодіжних підприємств у буквальному розумінні передбачає отримання певної віддачі від залучених фінансових ресурсів, а також, як зауважують А.В. Чупіс і С.Н. Закоморний, раціональний розподіл їх вкладення, що дає змогу при оптимальному співвідношенні альтернативних джерел фінансування отримати найвищий результат від їх використання [2, с. 12]. Із метою визначення рівня ефективності необхідно перш за все сформулювати критерії, за якими передбачається його оцінювати, які повинні відображати, якою «мірою або ступенем здійснення господарських заходів він наближає» інноваційне підприємство до досягнення мети фінансування [3]. Так, головним критерієм ефективності фінансування Н.А. Гринюк вважає максимізацію фінансової рентабельності підприємства за збереження рівня його фінансової стійкості [4, с. 213]. I.Т. Балабанов звертає увагу на величину прибутку, що приходиться на одиницю вкладеного капіталу [5, с. 445]. Натомість на рівні ефекту та ефективності використання фінансового ресурсу акцентують увагу В.Г. Федоренко та Ю.Б. Пінчук [6, с. 3-5].

Крім того, під час визначення структури джерел фінансування Ю. Воробйов, Б. Холод та інші пропонують звертати увагу на такі критерії, як: питома вага власних фінансових ресурсів у сукупних фінансових ресурсах підприємства; питома вага статутного (акціонерного, пайового, неподільного, індивідуального) капіталу підприємства в сукупних фінансових ресурсах; питома вага позикових коштів у сукупних фінансових ресурсах; питома вага довгострокових позикових коштів у сукупних фінансових ресурсах; питома вага довгострокових позикових коштів у загальній сумі позикових коштів підприємства; питома вага довгострокових банківських кредитів у сукупних фінансових ресурсах; питома вага довгострокових банківських кредитів у загальній сумі позикових коштів підприємства [7, с. 132]. Таким чином, автори з метою оцінки економічної ефективності фінансування пропонують використовувати показники трьох груп: показники, які 
характеризують вартість формування фінансових ресурсів, показники, які характеризують рентабельність фінансових ресурсів, та показники, які характеризують оборотність фінансових ресурсів [7, с. 134]. Також оцінку ефективності використання фінансових ресурсів для фінансування інноваційної діяльності молодіжних підприємств пропонують здійснювати за такими показниками ефективності використання власних та позикових фінансових, які включають термін окупності, коефіцієнт оборотності; рентабельність позикових і власних фінансових ресурсів.

На відміну від вище зазначених вчених, А.В. Чупіс базовим критерієм вважає максимальне зростання доходу (а саме суми амортизаційних відрахувань, балансового прибутку та заробітної плати) від залучених у виробництво джерел фінансування [3, с. 47]. Під час вибору джерела фінансування інноваційної діяльності молодіжних підприємств деякі науковці, серед яких А. Пересада [8], А. Давидов, В. Кузьмінський [9], пропонують дотримуватися критерію мінімізації вартості фінансових ресурсів, у запропонованій методиці розрахунку якого не враховано зростання їхньої вартості 3 часом. В.В. Ковальов, С. Брігхем, Л. Гапенські та інші зауважують пріоритетність сформованої структури фінансування, яка ефективно діяла на підприємстві, а тому під час фінансування інноваційної діяльності молодіжних підприємств необхідно дотримуватися саме раніше діючого асортименту фінансових ресурсів. Але звернемо увагу, що автори не дають відповіді на питання, яким чином здійснювати фінансування діяльності у разі неефективності існуючого алгоритму фінансування або обмеженості їхніх обсягів, а також ігнорують інші критерії, які впливають на структуру джерел фінансування, тому, на нашу думку, цей підхід не відповідає особливостям інноваційної діяльності молодіжних підприємств.

Вважаємо, що найбільш вагомими критеріями оцінки ефективності фінансування інноваційної діяльності молодіжних підприємств повинні бути показники, які віддзеркалюють економічну доцільність тих чи інших альтернативних джерел, а саме: цільове призначення фінансових ресурсів та їхній сумарний обсяг; термін окупності; річний прибуток від інноваційної діяльності молодіжного підприємства; теперішня вартість залучених фінансових ресурсів (чистий приведений ефект); рівень прибутковості (індекс прибутковості або рентабельності) та рентабельність капіталу (норма рентабельності інвестицій); внутрішня ставка доходності; точка беззбитковості (рис. 1).

Термін окупності інвестованих фінансових ресурсів для фінансування інноваційної діяльності молодіжних підприємств визначається співвідношенням суми первісних інвестицій до середньорічного розміру прибутку [5]. Чистий приведений ефект (NPV) є різницею між сумою чистих грошових потоків, приведених до теперішнього часу, i сумою інвестиційних витрат, приведених до теперішнього часу за однаковими коефіцієнтами дисконтування. Норма рентабельності інвестицій (IRR) відображає максимально допустимий відносний рівень витрат, які можуть бути асоційовані 3 певним інноваційним проектом, який є об'єктом фінансування інноваційної діяльності молодіжних підприємств. Індекс прибутковості (рентабельності) фінансових ресурсів, інвестованих у фінансування інноваційної діяльності молодіжних підприємств, повинен визначатися за формулою 1.

$$
P I=\sum \frac{P k}{(1+r)^{k}} / I C,
$$

де $P k$ - прогнозований дохід за роками;

$r$ - ставка дисконту;

IC- первісні інвестиції [8].

Звернемо увагу, що на ефективність фінансування інноваційної діяльності молодіжних підприємств впливає оптимальність співвідношення внутрішніх та зовнішніх джерел, яка, як зауважують В.М. Гриньова, В.О. Коюда, Т.I. Лепейко та О.П. Коюда, повинна відповідати таким критеріям, як: необхідність забезпечення фінансової 


\section{Критерії оцінки ефективності фінансування інноваційної діяльності молодіжних підприємств}

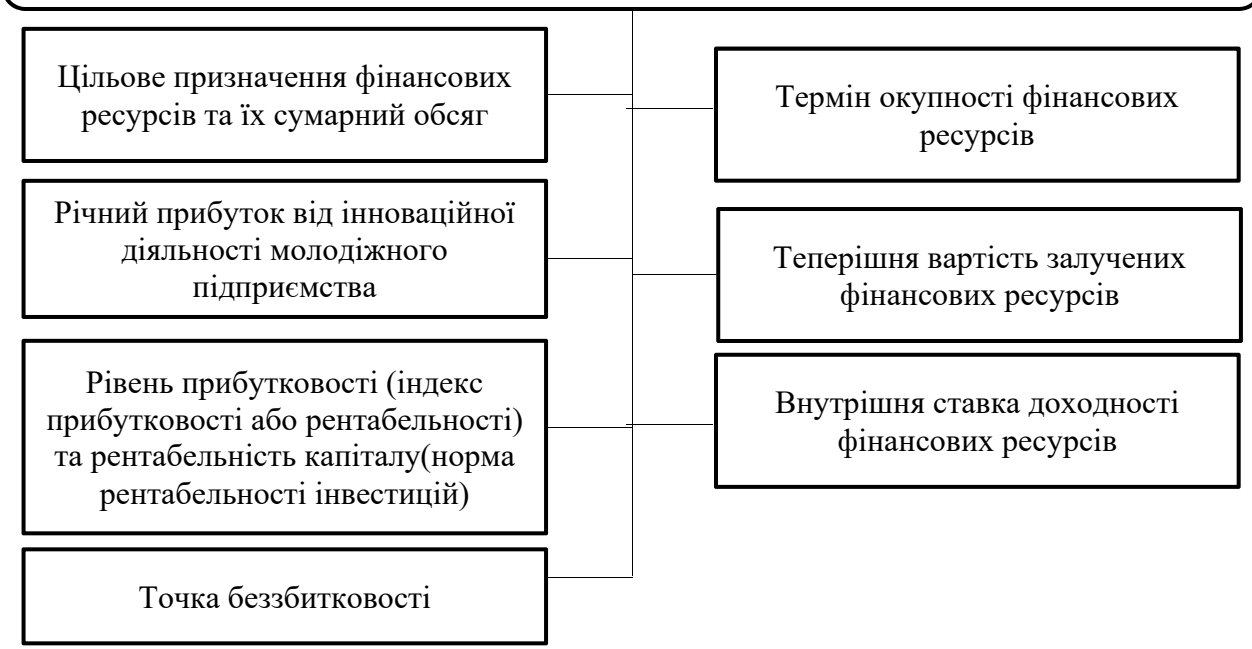

Рис. 1. Критерії очінки ефективності фінансування інноваційної діяльності молодіжних підприємств

Джерело: згруповано авторами за даними [3-7]

стійкості господарюючого суб'єкта; максимізація суми прибутку, який залишається у власності підприємства за різних співвідношень джерел; показники використання різних фінансових ресурсів за попередні періоди. Таким чином, визначення допустимості тих чи інших форм фінансування дозволяє обгрунтувати оптимальну структуру джерел, яка забезпечить його максимальну ефективність.

Зауважимо, що на аналіз ефективності залучення додаткових грошових коштів впливає низка факторів, які умовно поділяються на кількісні та якісні. До кількісних варто віднести такі, як: обсяги фінансування; структура матеріальних витрат; ціна продажу інновацій; собівартість реалізації; вартість залучених джерел; ресурсовіддача; оборотність дебіторської заборгованості; оборотність запасів; співвідношення власного та залученого фінансування; параметри прибутковості; параметри затрат на оплату праці; обсяги державного фінансування; структура джерел фінансування; трансакційні витрати; спеціалізація інноваційної діяльності; ритмічність, своєчасність, насиченість грошового потоку та інші. Якісні фактори, які впливають на ефективність фінансування інноваційної діяльності молодіжних підприємств, умовно поділяються на такі, як: наявність і реальність концепції інноваційного розвитку підприємства; освіта, досвід та імідж адміністративного персоналу; репутація підприємства; дотримання договірної та платіжної дисципліни; вміння своєчасно та адекватно реагувати на ризики; дієвість систем моніторингу та контролю; плинність кадрів; організаційна структура підприємства; рівень відповідності якості продукції їхнім цінам та ринковим тенденціям; якість маркетингової політики та збуту продукції; структура готової продукції і відповідність ринковому сегменту; доступність до умов кредитування та інші [9-14] (рис. 2).

Оскільки структура джерел фінансування інноваційної діяльності молодіжних підприємств може мати різний асортимент, ефективність фінансування за кожним iз них можна оцінити, грунтуючись на їхніх особливостях. Зупинимось на деяких із них більш детально. У структурі джерел фінансування інноваційної діяльності моло- 


\section{Фактори, які впливають на оцінку ефективності фінансування інноваційної діяльності молодіжних підприсмств}

обсяги фінансування;

структура матеріальних витрат; ціна продажу інновацій; собівартість реалізації; вартість залучених джерел; ресурсовіддача;

оборотність дебіторської

заборгованості;

оборотність запасів; співвідношення власного та залученого

фінансування;

параметри прибутковості;

параметри затрат на оплату праці; обсяги державного фінансування; структура джерел фінансування; трансакційні витрати; спеціалізація інноваційної діяльності; ритмічність, своєчасність, насиченість грошового потоку та інші.

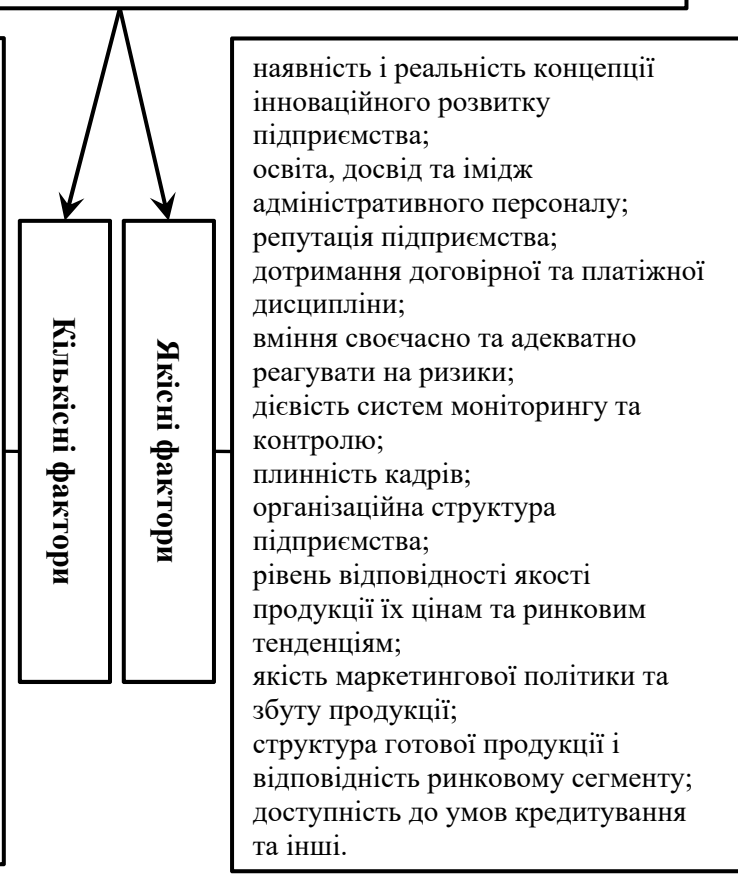

Рис. 2. Фактори, які впливають на оиінку ефективності фінансування інноваційної діяльності молодіжних підприємств

Джерело: згруповано автором за даними [11-14]

діжних підприємств важливе місце посідає наявність бюджетних коштів. Держава $є$ важливим елементом інноваційних процесів у економіці, зокрема у молодіжних підприємствах, оскільки має не лише законодавчо-нормативний вплив, а й здійснює їх фінансову підтримку. Зауважимо, що державне фінансування реалізується у формі цільового безповоротного фінансування, цільового субсидування, державного замовлення, пільгового оподаткування, звільнення від сплати окремих видів податків та державного кредитування (у формі надання прямих гарантованих державних позик, відкриття державних кредитних ліні, пільгового (повного або часткового) безвідсоткового державного кредитування, повної або часткової компенсації відсотків за кредитами, а також державного гарантування кредитів) [1, с. 241]. Визначення ефективності бюджетного кредитування або інвестування слід здійснювати, грунтуючись на відповідній методиці оцінки. Звернемо увагу, що, як підтверджує світовий досвід, головним фінансовим інструментом стимулювання інноваційного розвитку молодіжних підприємств $є$ використання коштів державного бюджету, а основним показником, який визначає рівень відповідальності науки завданням інноваційного розвитку економіки, є наукоємність ВВП, тобто частка державних видатків на НДДКР у ВВП $[1$, c. 242]. Тому визначення частки бюджетних витрат на фінансування інноваційної діяльності молодіжних підприємств дозволить виявити роль, місце та вплив країни на даний процес, а також проаналізувати його сучасні тенденції й напрями покращення ефективності використання державних коштів для забезпечення інноваційного роз- 
витку галузі. Отже, оцінка ефективності бюджетного фінансування повинна здійснюватися з урахуванням форми державної підтримки.

У випадку використання самофінансування як форми фінансування інноваційної діяльності рішення про вкладення грошових коштів приймає молодіжне підприємство, керуючись внутрішніми обмеженнями, до яких варто віднести в першу чергу вартість капіталу й власні потреби виробництва; а також грунтуючись на зовнішніх чинниках, серед яких - ставка банківських депозитів, ціна залученого капіталу, умови галузевої та міжгалузевої конкуренції. Тому оцінка ефективності власного фінансування інноваційної діяльності повинна здійснюватися із урахуванням цих критеріїв.

Оцінка фінансування інноваційної діяльності при внутрішньому та зовнішньому інвестуванні має здійснюватися за методикою оцінки економічної ефективності інвестицій, яка на думку Л.Д. Загвойської, Т.С. Маселко, М.М. Якуби та багатьох інших авторитетних учених, має бути статистичною або динамічною [12]. Зауважимо, що статистичні або прості методи оцінки інвестицій не враховують вплив часу та включають розрахунок річного прибутку, терміну окупності витрат, рентабельності та точки беззбитковості, а тому не поширені у практиці оцінки ефективності фінансування інноваційної діяльності молодіжних підприємств. Тому головною та суттєво важливою відмінністю динамічного методу оцінки є дисконтування грошових потоків, за допомогою якого суб'єкти інноваційної діяльності мають змогу передбачити та виразити математично майбутню вартість фінансових ресурсів та їх зміну у часі. Серед найважливіших динамічних показників оцінки інвестицій в інноваційну діяльність $є$ чиста теперішня (приведена) вартість, внутрішня норма рентабельності інвестицій, рентабельність інвестицій (або індекс рентабельності інвестицій) та дисконтований термін окупності інвестицій [14].

Варто зазначити, що як джерело фінансування для здійснення інноваційної діяльності молодіжні підприємства активно використовують також позикові кредитні ресурси, переважно банківські, оцінка ефективності залучення яких здійснюється за трьома основними методиками [3-5]. У першому випадку, прихильником якого є Ю.В. Прохоров, економічно ефективним фінансування інноваційної діяльності господарюючого суб'єкта за рахунок банківського кредитування є доцільним за умови перевищення рівня рентабельності реалізованого проекту над рівнем кредитного відсотка [3]. Натомість за іншим підходом методики оцінки передбачається співвідношення відсоткової ставки та внутрішньої ставки доходу інноваційного проекту, що є об'єктом фінансування [12]. За третім підходом передбачається порівняння рівня рентабельності інноваційного проекту та середньозваженої вартості кредитних ресурсів, які виступають джерелом фінансування інноваційної діяльності молодіжного підприємства.

Звернемо увагу, що суттєвим недоліком цих методик є відсутність врахування фактора часу, який впливає на вартість позикових ресурсів. Тому В.І. Прокопенко, О.Ю. Смельянов та А.С. Гавриляк $[12 ; 14]$ пропонують аналітичний вираз для визначення цього терміна за умови, що проект фінансується повністю за рахунок позикових коштів, розраховувати за формулою 2 :

$$
\frac{\Pi_{\text {д }} * \alpha}{E_{\%}} *\left(1-\left(1+E_{\%}\right)^{-T_{\Pi}}\right)=K,
$$

де Пд - річний дохід від реалізації інноваційного проекту;

$\alpha$ - частка доходу, яка спрямовується на погашення позики;

$E_{\%}$ - ставка банківського відсотка за користування позикою;

$T_{n}$ - термін повернення позики;

$K^{n}$ - вартість інноваційного проекту.

У разі необхідності пришвидшення повернення кредитних ресурсів, молодіжне підприємство спрямовує на погашення позики весь дохід від інноваційної діяльності (тобто $\alpha=1$ ). Тоді формула матиме вигляд: 


$$
T_{\Pi}=\frac{1}{E_{\%}} \ln \left[\frac{\Pi_{\text {Д }}}{\Pi_{\text {Д }}-K^{*} E_{\%}}\right] .
$$

Звернемо увагу, що вважається економічно недоцільним залучати позикові фінансові ресурси у інвестування молодіжних підприємств, коли термін повернення позики перевищує термін експлуатації засобів праці. Але, використовуючи методи аналізу В.І. Прокопенко, О.Ю. Смельянов та А.С. Гавриляк $[2 ; 14]$ нівелюють це твердження, а саме (формула 4):

$$
\frac{1}{E_{\%}} \ln \left[\frac{E_{\text {пा }}+E_{a}}{E_{\text {пр }}+E_{a}-E_{\%}}\right] \prec \frac{1}{E_{a}} .
$$

Автори звертають увагу, що аналіз нерівності (формула 4) дає змогу зробити висновок, зокрема, про те, що у разі, коли рентабельність інноваційної діяльності молодіжного підприємства дорівнює ставці банківського відсотка, іiі фінансування за рахунок кредитних ресурсів $є$ доцільною, оскільки нерівність $\frac{1}{E_{\%}} \ln \left[\frac{E_{\text {пР }}+E_{a}}{E_{\text {пр }}+E_{a}-E_{\%}}\right] \prec \frac{1}{E_{a}}$ виконується завжди. Для обгрунтування останньої тези необхідно помножити ліву та праву частини нерівності (4) на $E_{\%}$ та елімінувати з даної нерівності показник $E_{\text {ПРP }}$, прийнявши, що $E_{\Pi р}=E_{\%}$. Тоді значення лівої частини, отриманої такими перетвореннями нерівності, буде завжди меншим, ніж значення правої іï частини. Для того, щоб переконатися у цьому, достатньо взяти експоненту з лівої та правої частини цієї нерівності та розкласти в ряд праву частину отриманого виразу. Отже, згідно з формулою 4, перевищення кредитного відсотка над значенням рентабельності інноваційного проекту не $\epsilon$ обов' язковою умовою визнання недоцільним взяття позики для його фінансування молодіжним підприємством, оскільки навіть за такої умови нерівність $\frac{1}{E_{\%}} \ln \left[\frac{E_{\text {ПР }}+E_{a}}{E_{\text {пр }}+E_{a}-E_{\%}}\right] \prec \frac{1}{E_{a}}$ може виконуватися. Цей висновок, що суперечить одному з традиційних підходів до оцінки доцільності взяття позики, свідчить про необхідність при формулюванні критеріїв такої оцінки ретельно враховувати усі найважливіші чинники, що впливають на ефективність використання отриманої позики, зокрема, часових параметрів кредитування інноваційних проектів.

Науковці В.І. Прокопенко, О.Ю. Смельянов та А.С. Гавриляк [14] зауважують, що перевищення ставки кредитного відсотка над рентабельністю інноваційного проекту не є обов'язковою умовою для визнання недоцільності здійснення цього проекту. Проте перевищення прибутку від реалізації проекту над сумою сплачених відсотків за кредитом, який використовується для фінансування даного проекту є необхідною умовою доцільності здійснення проекту, що розглядається. Автори зауважують, що можна побудувати таку схему фінансування інноваційного проекту, за якої невиконання останньої умови не обов'язково буде свідчити про необхідність відмови від реалізації цього проекту. Резюмуючи усе вищевикладене, можна зробити висновок про те, що побудова критеріальних показників оцінки доцільності залучення позикових коштів 3 метою фінансування інноваційної діяльності молодіжних підприємств потребує обов'язкового урахування часових параметрів кредитування цих проектів, зокрема, терміну повернення отриманих для їх фінансування кредитних ресурсів [14].

Висновки. Таким чином, методика оцінки ефективності фінансування інноваційної діяльності молодіжних підприємств залежить від вибору форми та джерел фінансування, а тому має суттєві відмінності. Головними критеріями визначення ефективності фінансування є цільове призначення фінансових ресурсів та їх сумарний обсяг; термін окупності; річний прибуток від інноваційної діяльності молодіжного підприємства; теперішня вартість залучених фінансових ресурсів (чистий приведений 
ефект); рівень прибутковості (індекс прибутковості або рентабельності) та рентабельність капіталу (норма рентабельності інвестицій); внутрішня ставка доходності; точка беззбитковості.

\section{Список використаних джерел:}

1. Мельник Ю.Ф., Саблук П.Т. Агропромислове виробництво України: уроки 2018 року і шляхи забезпечення інноваційного розвитку. Економіка АПК. 2019. Вип. 31. С. 3-15.

2. Чупис А.В., Закоморный С.Н. Эффективность использования финансовых ресурсов предприятия. Сумы, 1997. 28c.

3. Финансовое положение предприятия (оценка, анализ, планирование) / под ред. д.э.н., проф. А.В. Чуписа. Сумы : Издательство “Университетская книга", 1999. 332 с.

4. Гринюк Н.А. Критерії оптимальності управління структурою фінансових ресурсів торговельного підприємства. Економіка і підприємництво: стан та перспективи. Економіка $і$ підприсмництво: стан та перспективи. Дніпропетровськ : ДНУ, 2003. С. 204-213.

5. Балабанов И.Т. Основы финансового менеджмента. Москва : Финансы и статистика, $1998.512 \mathrm{c}$.

6. Федоренко В.Г., Пінчук Ю.Б. Удосконалення структури фінансового забезпечення інвестиційно-інноваційної діяльності підприємств. Інвестиції: практика та досвід. 2018. № 17. C. 3-5.

7. Воробйов Ю., Холод Б. Управління ресурсами підприємства : навчальний посібник. Київ : Центр навчальної літератури, 2014. 288 с.

8. Пересада А.А. Управління інвестиційним процесом. Київ : Лібра, 2002. 472 с.

9. Дорошенко Т. Формування оптимальної структури інвестиційних ресурсів на підприємстві. Фінанси Украӥни. 2012. № 9. С. 134-137.

10. Petrenko V., Karnaushenko A. Jont enterprises in foreign trade activity of Ukraine. Baltic Journal of Economic Studies, 2017. no. 3 (5), pp. 203-207 http://dx.doi.org/10.30525/2256-0742/2 017-3-5-203-207.

11. Ihnatenko M., Marmul L., Petrenko V., Karnaushenko A., Levaieva L. Innovative Tools in the Methodology and Teaching of the Basic Principles of Enterprise Management. International Journal of Management, 2020. No. 11 (6), pp. 847-854. URL: http://dx.doi.org/10.34218/IJM.11.6.2020.073.

12. Петренко В.С., Карнаушенко А.С. Формування молодіжного підприємництва в Україні та аналіз факторів впливу на його розвиток. Фінансовий простір. 2019. № 3. С. 139-147. DOI: https://doi.org/10.18371/fp.3(35).2019.190170.

13. Rusnak A.V., Karnaushenko A.S., Petrenko V.S. Legislative Support of Innovation Activity in Ukraine: Problems and Ways to Overcome Them. Ефективна економіка. 2018. № 10. URL: http://www.economy.nayka.com.ua/pdf/10 2018/4.pdf (дата звернення: 14.10.2020).

14. Танклевська Н.С., Карнаушенко А.С. Розвиток фінансування інноваційної діяльності сільськогосподарських підприємств : монографія. Херсон : Айлант, 2015. 184 с.

\section{References:}

1. Melnik Y.F., Sabluk P.T. (2019) Ahropromyslove vyrobnytstvo Ukrayiny: uroky 2018 roku i shlyakhy zabezpechennya innovatsiynoho rozvytku [Agro-industrial production of Ukraine: lessons of 2018 and ways to ensure innovative development]. Ekonomika APK, no. 31, pp. 3-15.

2. Chupis A.V., Zakomorny S.N. (1997) Effektivnost' ispol'zovaniya finansovykh resursov predpriyatiya [Efficiency of using the financial resources of the enterprise]. Sumy: Publishing House "University Book". (in Ukrainian)

3. Chupisa A.V. (ed.) (1999) Finansovoye polozheniye predpriyatiya (otsenka, analiz, planirovaniye) [The financial position of the enterprise (assessment, analysis, planning)], Sumy: Publishing House «University Book». (in Ukrainian)

4. Grinyuk N.A. (2003) Kryteriyi optymal'nosti upravlinnya strukturoyu finansovykh resursiv torhovel'noho pidpryyemstva [Criteria for optimal management of the structure of financial resources of a commercial enterprise]. Ekonomika i pidpryyemnytstvo: stan ta perspektyvy. Pp. 204-213.

5. Balabanov I.T. (1998) Osnovy finansovogo menedzhmenta [Fundamentals of financial management]. Moscow. (in Russian)

6. Fedorenko V.G., Pinchuk Y.B. (2018) Udoskonalennya struktury finansovoho zabezpechennya investytsiyno-innovatsiynoyi diyal'nosti pidpryyemstv [Improving the structure of financial 
support for investment and innovation activities of enterprises]. Investytsiyi: praktyka ta dosvid, no. 17 , pp. $3-5$.

7. Vorobyov Y., Kholod B. (2014) Upravlinnya resursamy pidpryyemstva [Management of enterprise resources]. Kyiv: Center for Educational Literature. (in Ukrainian)

8. Peresada A.A. (2002) Upravlinnya investytsiynym protsesom [Investment process management]. Kyiv. (in Ukrainian)

9. Doroshenko T. (2012) Formuvannya optymal'noyi struktury investytsiynykh resursiv na pidpryyemstvi. [Formation of the optimal structure of investment resources at the enterprise]. Finansy Ukrayiny, no. 9, pp. 134-137.

10. Petrenko V. Karnaushenko A. (2017) Jont enterprises in foreign trade activity of Ukraine. Baltic Journal of Economic Studies, no. 3 (5), pp. 203-207 Available at: http://dx.doi.org/10.30525/2 256-0742/2017-3-5-203-207.

11. Ihnatenko M., Marmul L., Petrenko V., Karnaushenko A., Levaieva L. (2020) Innovative Tools in the Methodology and Teaching of the Basic Principles of Enterprise Management. International Journal of Management, no. 11 (6), pp. 847-854. Available at: http://dx.doi.org/10.34218/ IJM.11.6.2020.073.

12. Petrenko V.S., Karnaushenko A.S. (2019) Formuvannya molodizhnoho pidpryyemnytstva v Ukrayini ta analiz faktoriv vplyvu na yoho rozvytok [Formation of youth entrepreneurship in Ukraine and analysis of factors influencing its development]. Finansovyy prostir, no. 3, pp. 139-147.

13. Rusnak A.V., Karnaushenko A.S., Petrenko V.S. (2018) Legislative Support of Innovation Activity in Ukraine: Problems and Ways to Overcome Them. Efficient economy, no. 10. URL: http://www.economy.nayka.com.ua/pdf/10_2018/4.pdf (accessed 14 October 2020).

14. Tanklevskaya N.S., Karnaushenko A.S. (2015) Rozvytok finansuvannya innovatsiynoyi diyal'nosti sil's'kohospodars'kykh pidpryyemstv [Development of financing of innovative activity of agricultural enterprises]. Kherson: Atlant. (in Ukrainian) 